\title{
IMPACT OF FEEDING SOME FODDER TREES AND TREATED CROP RESIDUES ON BARKI LAMBS PERFORMANCE UNDER SEMI-ARID AREA OF EGYPT
}

\author{
M. M. Eissa, W. M. A. Sadek, A. R. Khattab, A. EL-Wakeel. EL. and A. M. Saber
}

Animal Production Research Institute, ARC, Dokki, Giza, Egypt

\section{SUMMARY}

Thirty Barki lambs with average body weight of $9.77 \pm 0.50 \mathrm{~kg}, 3$ months age were divided randomly by weight into three equal groups, to study the effect of supplementary values of tree fodder (Cassava or Prosopis) with ammoniated wheat straw on growth performance, blood metabolic, feed efficiency and economic efficiency of growing Barki lambs. The crude protein $(C P)$ requirements of growing sheep (NRC, 1985) were covered from concentrate feed mixture (CFM) 40\%. The other 60\% of CP was covered from: berseem hay in the first group $\left(G_{1}\right), 50 \%$ Prosopis $+50 \%$ a treated wheat straw in second group $\left(G_{2}\right), 50 \%$ Cassava $+50 \%$ a treated wheat straw in third group $\left(G_{3}\right)$. The feeding trails lasted for 16 weeks. The obtained results showed that the crud protein $(C P)$ content were noticeably higher with G3 (15.56\%) than those of G1 (14.61\%) or G2 (14.10\%). the content of DM, $O M$ and NFE were higher (93.55, 88.53 and 51.97\%) in berseem hay ration compared with the other experimental rations. Moreover, the lowest value of CF (42.21\%) was recorded with berseem hay ration and the highest value (48.12\%) was detected with G3. On the other hand, the content of Hemicellulose was more in G3 compared with other groups G2 and G1 (19.10 vs.8.70 and 6.10\% of DM, respectively). Cellulose was higher (23.5\% of DM) with G2 than the other G1 and G3 (16.00 and 9.5\% of DM, respectively). The differences in EE, NDF and $A D L$ were of fewer values. The methane production with second combination Cassava: treated wheat straw was more than first combination Prosopis: treated wheat straw (12 vs. $10 \mathrm{ml} / 200 \mathrm{mg}$ DM, respectively). Whereas, fist combination was contained more condensed tannins (CT), compared with second combination (23 vs. $20 \mathrm{~g} / \mathrm{kg} \mathrm{DM,}$ respectively). The highest value of final body weight $(F B W)$ and total body gain $(T B G)$ were recorded with G3 (31.33 and $21.41 \mathrm{~kg}$, respectively) then $\mathrm{Gl}$ (30.74 and $20.90 \mathrm{~kg}$, respectively) but, lowest values were detected with G2 (27.94 and $18.18 \mathrm{~kg}$, respectively) and the differences were significant. Similarly, in daily body gain (DBG) this improvement could be attributed to increase in dry matter intake (DMI, g/h/d) in G1 and G3 compared with G2 (942 and 804 vs. 738, respectively). Most tested blood parameters were significantly affected by dietary treatments. The economic efficiency (EE) was better with G3 then G2, compared with G1. Accordingly, feeding Cassava or Prosopis (leaves \& twigs) with ammoniated wheat straw at $60 \%$ (instead of berseem hay) $+40 \%$ concentrate feed mixture level has better impact on growing Barki lambs either for growth rate or feed conversion efficiency and economic values.

\section{Keywords: Barki sheep, legume trees, growth performance, economic efficiency.}

\section{INTRODUCTION}

Feed shortage will be increased in the next decades due to the expected global climate changes which will lead to increase desertification in many arid and semi-arid areas of the world that leads to; accelerate soil erosion by wind and water; increasing salinity in water wells and soil with rain drop. These phenomena will lead to despair the natural range plant cover. Halophytes are widely distributed in high density in these areas under harsh conditions. This refers to their high resistance to salinity in water and/ or soil especially during dry periods preventing soil erosion. So, feeding halophytes is a feasible solution to minimize the expected problems of feed shortage in such areas. The suitable halophytic forage species that show better adaptability and chances of establishment are
Prosopis juliflora and Cassava. Prosopis juliflora is one of the rangeland trees that can grow in a wide range of soil and climatic conditions. It is a genus of trees and shrubs in the legume family (Leguminosae, subfamily Mimosoideae), native to arid and semi-arid regions of the Americas, it is a valuable multipurpose resource that provides timber, firewood, livestock feed, human food, shade, shelter and soil improvement (Pasiecznik et al., 2001). Cassava (Manihot esculenta Crantz) is a perennial woody shrub of the family Euphorbiaceae. It originated in South America and is extensively cultivated as an annual crop in the tropics and sub-tropics for the dual purposes of tuberous roots as a source of energy for humans and animals and foliage as a feed for

Issued by The Egyptian Society of Animal Production 
animals. Cassava foliage is recognized as a source of undegraded protein with a high content of digestible nutrients for both non-ruminants and ruminants (Wanapat, 2001). The foliage can be used as a supplement for animals in either fresh or wilted form or as hay (Phengvichith \& Ledin, 2007 and Wanapat et al., 1997). The use of fodder trees and shrubs to solve the attendant problems of low productivity in small ruminant production has received research attention in recent times (El Shaer, 2010). However, such trees and shrubs foliage are generally rich in antnutritional factors, particularly tannins (Makkar, 2003). Feeding a mixture of these fodder shrubs could minimize and overcome the problems of palatability and toxic effects (Lowry, 1990, Yusran and Teleni, 2000, Anbarasu et al., 2001, Patra et al., 2002 and El Shaer, 2010).

Thus, this study aimed at evaluating the possible effects of feeding a mixture of Prosopis juliflora or Cassava shrubs with ammoniated wheat straw on growing performance and economic return of Barki lambs in semi-arid areas of Egypt.

\section{MATERIAL AND METHODS}

This study was conducted at Animal Production Research Station, Borg El Arab, belonging to Animal Production Research Institute, Agricultural Research Center, Egypt.

Thirty Barki lambs, selected from Borg El Arab Station Herd, with an average age of 3 months and $9.77 \pm 0.50 \mathrm{~kg}$ body weight were used. The animals were divided randomly according to body weight into three similar groups, 10 lambs each. The animals were weighed at the beginning then biweekly. Animals were fed for two weeks as a transitional period on the tested experimental rations before the start of the experimental work. Feeding the experimental rations lasted for 16 weeks. The crude protein $(\mathrm{CP})$ requirements of growing sheep (NRC, 1985) were covered from concentrate feed mixture (CFM) $40 \%$. The other $60 \%$ of CP was covered from: berseem hay in the first group $\left(\mathrm{G}_{1}\right), 50 \%$ Prosopis $+50 \%$ treated wheat straw in second group $\left(\mathrm{G}_{2}\right)$, and $50 \%$ Cassava $50 \%$ treated wheat straw in third group $\left(\mathrm{G}_{3}\right)$.

The animals were fed in groups. The berseem hay and treated wheat straw (by injecting ammonia) were cultivated in Borg El Arab Experimental Station, while Prosopis and Cassava (leaves \& twigs) were harvested along the sub-roads from Alexandria governorate during June and July in the summer to dry in shadow. The CFM consisted of $25 \%$ undecortecated cotton meal, $43 \%$ yellow corn, $25 \%$ wheat bran, $3.5 \%$ molasses, $2 \%$ limestone, $1 \%$ common salt and $0.5 \%$ minerals mixtures. The rations were offered in two equal meals at 8 a.m. and at 3.0 p.m. Water was available at all times.

The chemical composition of the tested ingredients consumed by Barki lambs is shown in Table (1). Acid detergent fibre (ADF) and neutral detergent fiber (NDF) were analyzed by the Van Soest method (Van Soest, 1965). Anti-nutrients determination: Tannin content was determined using the method described by Makkar (2003). Phytin was extracted and precipitated according to the method of Reed (1995). Quinones and glycosides content were determined using the procedure of Reed et al. (2000). Alkaloid was obtained by Harbone (1973) method while saponin was assayed by the test described by Wilson (1992).

Table 1.Chemical composition and cell wall constituents (\% on DM basis) of feed ingredients

\begin{tabular}{lcccccccccc}
\hline \multirow{2}{*}{ Item } & \multirow{2}{*}{ DM } & \multicolumn{4}{c}{ Chemical composition } & \multicolumn{4}{c}{ Fiber Fraction } \\
\cline { 3 - 10 } & & OM & CP & CF & EE & NFE & Ash & NDF & ADF & ADL \\
\hline Berseem hay & 95.12 & 89.59 & 10.64 & 38.54 & 1.03 & 39.38 & 10.41 & 55.89 & 43.27 & 37.16 \\
Prosopis Juliflora & 70.39 & 93.30 & 17.52 & 30.70 & 2.72 & 42.36 & 6.70 & 57.41 & 42.69 & 39.23 \\
Cassava & 44.39 & 88.26 & 22.94 & 28.05 & 2.92 & 34.35 & 11.74 & 35.49 & 26.29 & 19.47 \\
A treated Wheat Straw & 98.00 & 89.00 & 9.86 & 48.23 & 3.90 & 27.07 & 11.00 & 35.42 & 30.22 & 27.33 \\
CFM $^{*}$ & 91.20 & 93.90 & 15.70 & 14.23 & 3.13 & 60.84 & 6.10 & 43.00 & 17.30 & 5.80 \\
\hline
\end{tabular}

* Concentrate feed mixture ( CFM) consists of $25 \%$ undecortecated cotton meal, $43 \%$ yellow corn, $25 \%$ wheat bran, $3.5 \%$ molasses, $2 \%$ limestone, $1 \%$ common salt and $0.5 \%$ minerals mixtures.

Collected samples of (Prosopes Juliflora, and Cassava) were pooled and then dried in shadow, then sieved to pass through $1 \mathrm{~mm}$ sieve and stored in airtight polythene bags for further analysis. Similarly, samples of wheat straw were treated by injecting ammonia in the Borg El Arab Livestock Research Station. Samples of feeds were analyzed according to A.O.A.C (1995).

According to previous chemical analysis of two fodders leaves \& twigs viz (Prosopes Juliflora and Cacava) and treated wheat straw were then mixed in different combinations in different proportions and subjected to in vitro dry matter degradability as described by A.O.A.C (1995). This analysis was done to list the optimum tree fodder- crop residue combinations that gave the highest degradability. At the end of this analysis, based on the statistical analysis, a total of two promising combinations to determine methane concentration the gas was analyzed with a portable GASMET DX4030 gear using the $\mathrm{CO}_{2}$ Technique, which measure the $\mathrm{CO}_{2}$ content and then calculate the ration $\mathrm{CH}_{4} / \mathrm{CO}_{2}$ (Patra et al., 2006).

Blood samples were collected from the jugular vein once before feeding ( 3 animals in 
each) at the end of experimental period and centrifuged at $4000 \mathrm{rpm}$ for $20 \mathrm{~min}$. Part of the separated serum was directed to enzyme activity determination, while the other part was stored frozen at $-20^{\circ} \mathrm{C}$ till the biochemical analysis. Commercial kits were used for colorimetric biochemical determination.

Economic efficiency was calculated, as total output/ total input according to the local prices (where one ton $\mathrm{BH}=1600$ L.E.; CFM = 2800 L.E.; Cassava $=500$ L.E.; Prosopis Juliflora $=$ 500 L.E.; Treated wheat straw = 710 L.E.; Kg live body weight of lambs $=50$ L.E.

Data were statistically analyzed using OneWay Layout with Means Comparisons Procedure SAS (2003).

\section{RESULTS AND DISCUSSION}

\section{Chemical composition:}

The chemical composition of the experimental rations is presented in Table (2). It could be observed that $\mathrm{CP}$ content were noticeably higher with G3 $(15.56 \%)$ than those of G1 $(14.61 \%)$ or G2 $(14.10 \%)$. the content of DM, OM and NFE were higher $(93.55,88.53$ and $51.97 \%$ ) in berseem hay ration compared with the other experimental rations. Moreover, the lowest value (42.21) of CF was recorded with berseem hay and the highest value (48.12) was detected with G3. On the other hand, the content of Hemi-cellulose was more in G3, compared with other groups G2 and G1 (19.10 vs.8.70 and $6.10 \%$ of DM, respectively). Cellulose was higher $(23.5 \%)$ with G2 than the other G1 and G3 (16.00 and 9.5\%, respectively). The differences in EE, NDF and ADL were of fewer values. Nearly similar results were reported by Ben Salem et al. (2005), Fulkerson et al. (2008) and Afaf et al. (2010) on berssem hay. Shaker et al. (2014) on some salt tolerant fodder shrubs mixture. The variation among data in the literature could be due to the age of the leaves at harvest, the soil type and fertility as well as the agro-ecological system under which the trees were grown. According to Maasdorp et al. (1999), the plant species or variety, soil, climate, grazing, plant fraction and stage of maturity at sampling affect the nutritive value of forages. The non-fiber carbohydrates (NFC) were ranged from 28.81 to $38.61 \%$ in the presented experimental rations. Wheeler, (2003) reported that, the NFC levels in the total ration dry matter should not fall bellow 20 to $25 \%$ nor go above 40 to $45 \%$. Rations formulated for 35 to $37 \%$ NFC should avoid metabolic disturbances. The levels of ANF's (anti-nutritional factors) are varied from plant to plant and from season to season (El-Shaer et al., 2005). The condensed tannins (CTs) concentration ranged from 23 to 30 $\mathrm{g} / \mathrm{kg}$ DM as shown in Table (4). Until a few years ago, CTs were regarded as useless compounds with only negative effects on intake, digestion, production and reproduction in animals. Recent studies had confirmed that CTs may also had positive effects in ruminants (Barry and $\mathrm{McNabb}$, 1999 and Barry et al., 2001). The ideal CTs concentration for ruminant nutrition has been suggested to be in the range 20 to $40 \mathrm{~g} / \mathrm{kg} \mathrm{DM}$, increase the absorption of essential amino acids from small intestine and increased wool growth, milk secretion and reproductive rate without affecting voluntary feed intake, thus improving the efficiency of food conversion (Kumar, 2003).

Table 2. Chemical composition, cell wall constituents and phenols compounds of experimental ratios

\begin{tabular}{|c|c|c|c|}
\hline \multirow{2}{*}{ Item } & \multicolumn{3}{|c|}{ Groups } \\
\hline & G1 & G2 & G3 \\
\hline $\mathrm{DM}$ & 93.55 & 87.00 & 80.28 \\
\hline \multicolumn{4}{|l|}{ Chemical composition: } \\
\hline $\mathrm{OM}$ & 88.53 & 82.98 & 85.93 \\
\hline $\mathrm{CP}$ & 14.61 & 14.10 & 15.56 \\
\hline $\mathrm{CF}$ & 42.21 & 44.26 & 48.12 \\
\hline $\mathrm{EE}$ & 3.21 & 3.54 & 3.58 \\
\hline NFE & 25.50 & 21.08 & 18.67 \\
\hline Ash & 11.47 & 17.02 & 14.07 \\
\hline \multicolumn{4}{|l|}{ Fiber fraction $\%$ of DM: } \\
\hline NDF & 32.10 & 38.70 & 38.10 \\
\hline $\mathrm{ADF}$ & 26.00 & 30.00 & 19.00 \\
\hline Hemi-cellulose* & 6.10 & 8.70 & 19.10 \\
\hline Cellulose $* *$ & 16.00 & 23.50 & 9.50 \\
\hline ADL & 10.00 & 6.50 & 9.50 \\
\hline $\mathrm{NFC} * * *$ & 38.61 & 26.54 & 28.69 \\
\hline $\mathrm{NFC/NDF}$ & 1.20 & 0.69 & 0.75 \\
\hline \multicolumn{4}{|c|}{ Phenols compounds g/kg DM: } \\
\hline $\mathrm{TP}$ & 16.70 & 40.27 & 39.90 \\
\hline TT & 2.80 & 15.60 & 16.40 \\
\hline $\mathrm{CT}$ & 0.20 & 23.00 & 20.00 \\
\hline
\end{tabular}

* Hemi-cellulose $=$ NDF-ADF

$* *$ Cellulose $=$ ADF-ADL

***Non fiberous carbohydrates\%= OM\% - (CP\%+NDF\%+EE\%), Calsamiglia et al., 1995. 


\section{Methane production:}

Data of methane production are presented in Figure (1). The results indicated that the methane production with second combination Cassava: treated wheat straw more than first combination Prosopis: treated wheat straw (12 vs. $10 \mathrm{ml} / 200$ mg DM, respectively). Whereas, fist combination was contained more condensed tannins (CT) compared with second combination (23 vs. $20 \mathrm{~g} / \mathrm{kg} \mathrm{DM}$, respectively). Through feeding of tanniferous browse plants, it has been found to decrease methane production, which is beneficial for sparing of energy loss as methane (Babayemi et al., 2004 and Abdu et al., 2012) as an integrated part of carbohydrate metabolism (Demeyer and Van Nevel 1975). In this respect, Waghorn et al. (2002) showed that many types of forages known to contain condensed tannins had been shown to decrease methane production both in vivo and in vitro. So, it is beneficial for sparing of energy loss as methane. There was also a $16 \%$ reduction in methane production in lambs fed on Lolium pedunculatus, which is due to the presence of condensed tannins.

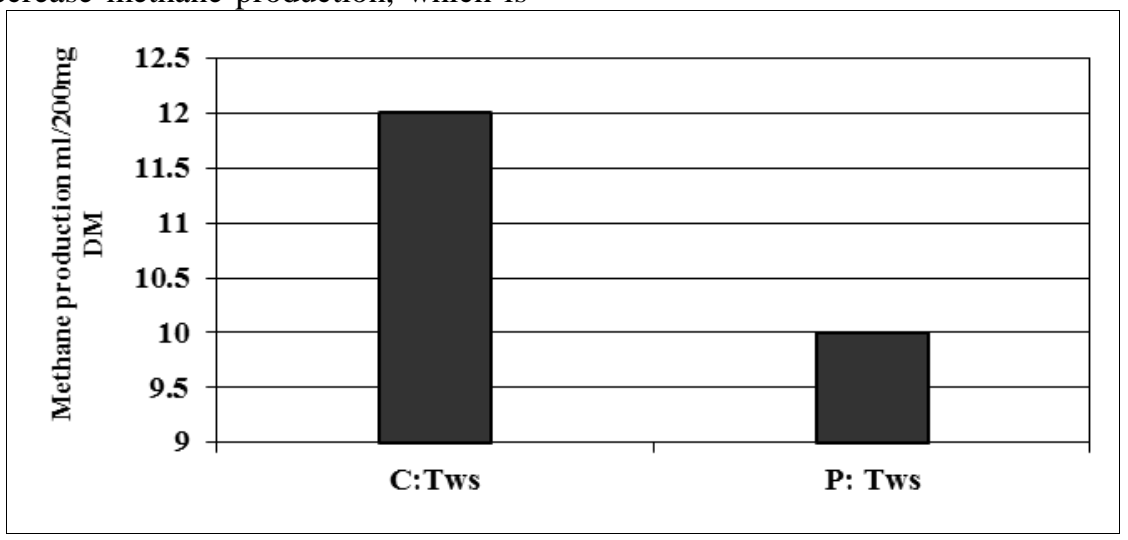

Fig. 1. Methane production from the experimental rations

\section{Performance of growing Barki lambs:}

As for growth performance, the obtained data in (Table 3 and Figure 2) indicated that the highest value of final body weight (FBW) and total body gain (TBG) was recorded with G3 (31.33 and $21.41 \mathrm{~kg}$, respectively) then G1 (30.74 and $20.90 \mathrm{~kg}$, respectively) but, lowest values were detected with G2 (27.94 and 18.18 $\mathrm{kg}$, respectively) and the differences were significant. Similarly, in daily body gain (DBG). This improvement could be attributed to increase in dry matter intake (DMI, g/h/d) in G1 and G3 compared with G2 (942 and 804 vs. 738, respectively). Similar results had been obtained by Aganga and Tshwenyane (2003) on Tswana goats fed forage tree legumes as supplements. They found that average daily gain slightly higher with significant increase in feed intake, conversion ratio. Low CT levels in several plant species, e.g. Acacia albida pods (Nsahlai et al., 1999), Lotus pedunculatus (Barry et al., 1986) and Acacia cyanophylla Lindl. (syn. Acacia saligna) foliage (Ben Salem et al., 2003) increased daily gain in sheep given protein-rich diets. This effect was ascribed to increased levels of post-ruminally available proteins.

Table 3. Growth performance of Barki lambs fed the experimental rations

\begin{tabular}{lccc}
\hline \multirow{2}{*}{ Item } & \multicolumn{3}{c}{ Groups } \\
\cline { 2 - 4 } & G1 & G2 & G3 \\
\hline No. of lambs & 10 & 10 & 10 \\
Feeding period, weeks & 16 & 16 & 16 \\
Initial weight, (kg) & $9.84 \pm 0.27$ & $9.76 \pm 0.32$ & $9.92 \pm 0.35$ \\
Final weight, ( kg) & $30.74 \pm 0.28^{\mathrm{a}}$ & $27.94 \pm 0.65^{\mathrm{b}}$ & $31.33 \pm 0.18^{\mathrm{a}}$ \\
Total gain, (kg) & $20.90 \pm 0.08^{\mathrm{a}}$ & $18.18 \pm 0.38^{\mathrm{b}}$ & $21.41 \pm 0.40^{\mathrm{a}}$ \\
Daily body gain, (g) & $174 \pm 0.64^{\mathrm{a}}$ & $152 \pm 3.14^{\mathrm{b}}$ & $178 \pm 3.36^{\mathrm{a}}$ \\
Daily feed intake: & & & \\
$\quad$ Berseem hay & 567 & - & - \\
$\quad$ Prosopis Juliflora & - & 224 & - \\
$\quad$ Cassava & - & - & 242 \\
$\quad$ A treated wheat straw & - & 214 & 241 \\
CFM & 375 & 300 & 321 \\
Total DMI (g/h/d) & 942 & 738 & 804 \\
DMI as \%BW & 3.74 & 3.11 & 3.16 \\
DMI g/kg BW ${ }^{0.75}$ & 83.80 & 68.59 & 70.91 \\
R/C & 1.51 & 1.46 & 1.51 \\
\hline
\end{tabular}

a-b Means in the same row with different superscripts differ significantly at $\mathrm{P}<0.05$. 


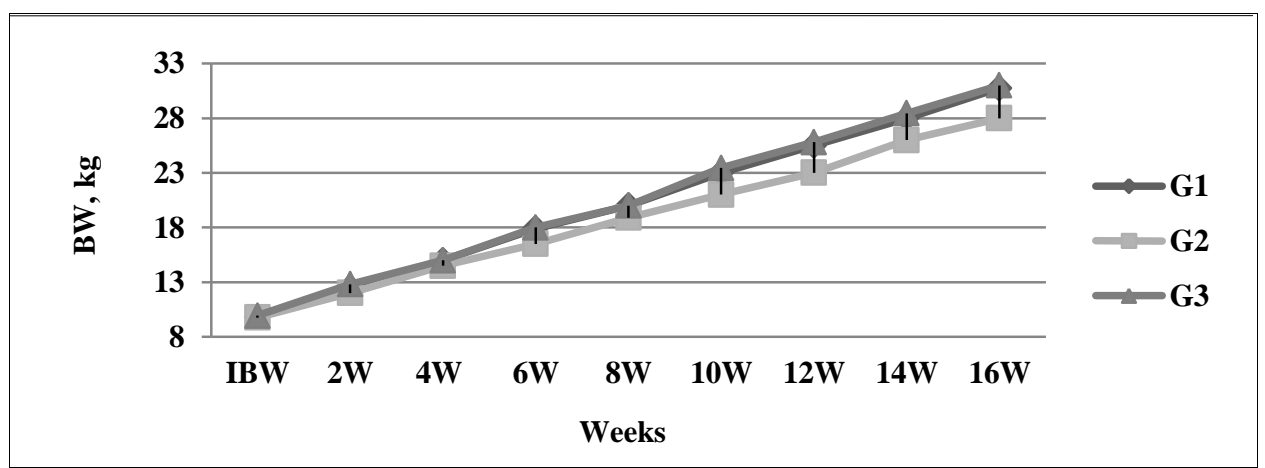

Fig. 2. Effect of experimental treatments on change in weight of Barki lambs

\section{Blood parameters:}

Data of blood serum parameters are presented in Table (4). The results indicated that most tested blood parameters were significantly affected by dietary treatments.

Serum total protein (TP) and albumin (A) were tended to be lower with G2 and G3 than G1 without significant $(\mathrm{P}>0.05)$ among them. Globulin concentration and $\mathrm{A} / \mathrm{G}$ ratio showed no significant differences between $\mathrm{G} 1$ and G3, but both were significantly higher $(\mathrm{P}>0.05)$ than those G2. While the highest values of glucose, serum urea, cearatinine and cholesterol concentrations were recorded $(\mathrm{P}>0.05)$ with $\mathrm{G} 1$ (60.01, 46.26, 1.95 and 72.08, respectively) in Barki lambs rations. However, the highest value of triglycerides was shown with $\mathrm{G} 2(\mathrm{P}>0.05)$, nevertheless the differences between G1 and G3 were insignificant. These findings are in accordance with those reported by Asker (1998) and Abdel- Halim (2003). Moreover, Shaker et al. (2008) working on growing Barki lambs and Badawy et al. (2002) on growing Barki lambs and Baladi kids reported that feeding fresh Acacia lowered TP, A and G values. The reduction of TP in animals fed salt shrubs might be owing to the high content of tannins in these plants. In agreement, Muller et al. (1989) and
Reed et al. (1990) reported that high content of tannins in acacia probably decreases the digestibility of crude protein. Coles (1986) found that poor absorption of dietary constituents from the intestinal tract leads to hypoproteinemia. Tannins can reduce digestibility of protein and carbohydrate by inhibiting digestive enzymes and by altering permeability of the gut wall (Streeter et al., 1993). Moreover, Ortiz et al. (1993) reported that tannins could adversely influence digestibility and absorption of nutrients such as proteins and amino acids, carbohydrates and lipids and also the activity of digestive enzymes. The obtained results are in harmony with those reported by Ismail et al. (2003) and Shaker et al. (2008).

The results (Table, 4) indicated also small fluctuations among groups rations in concentrations of ALT and phosphorus without significant differences, but the differences were significant with AST and calcium. The lowest values of ALT and calcium were recorded with G1 (17.33 u/l, and $171.80 \mathrm{mg} / \mathrm{dl}$, respectively). Generally, all obtained values are in line of blood parameters with findings of Shaker et al. (2014) when studied the effect of feeding salt tolerant fodder shrubs mixture on physiological performance of small ruminant.

Table 4. Effect of feeding experimental rations for Barki lambs on some blood serum parameters

\begin{tabular}{lccc}
\hline \multicolumn{1}{c}{ Items } & \multicolumn{3}{c}{ Groups } \\
\cline { 2 - 4 } & $\mathbf{G}_{\mathbf{1}}$ & $\mathbf{G}_{\mathbf{2}}$ & $\mathbf{G}_{\mathbf{3}}$ \\
\hline Glucose , mg/dl & $60.01 \pm 0.51^{\mathrm{a}}$ & $42.89 \pm 0.96^{\mathrm{b}}$ & $39.77 \pm 0.79^{\mathrm{c}}$ \\
Total protein, g/dl & $7.11 \pm 0.45$ & $6.21 \pm 0.48$ & $6.91 \pm 0.16$ \\
Albumin(A), g/dl & $2.80 \pm 0.19$ & $3.26 \pm 0.14$ & $2.96 \pm 0.17$ \\
Globulin(G), g/dl & $4.31 \pm 0.42^{\mathrm{a}}$ & $2.95 \pm 0.34^{\mathrm{b}}$ & $3.95 \pm 0.15^{\mathrm{a}}$ \\
A/G ratio & $0.66 \pm 0.08^{\mathrm{b}}$ & $1.13 \pm 0.09^{\mathrm{a}}$ & $0.75 \pm 0.06^{\mathrm{b}}$ \\
Urea, g/dl & $46.26 \pm 0.51^{\mathrm{a}}$ & $26.20 \pm 0.42^{\mathrm{c}}$ & $32.18 \pm 0.45^{\mathrm{b}}$ \\
Creatinine mg/dl & $1.95 \pm 0.16^{\mathrm{a}}$ & $1.01 \pm 0.15^{\mathrm{b}}$ & $1.65 \pm 0.14^{\mathrm{a}}$ \\
Cholesterol, mg/dl & $72.08 \pm 1.16^{\mathrm{a}}$ & $52.48 \pm 1.27^{\mathrm{b}}$ & $68.28 \pm 1.19^{\mathrm{b}}$ \\
Triglycerides mg/dl & $71.32 \pm 1.22^{\mathrm{b}}$ & $81.48 \pm 1.37^{\mathrm{a}}$ & $72.90 \pm 0.66^{\mathrm{b}}$ \\
AST, u/l & $29.50 \pm 0.59^{\mathrm{b}}$ & $36.20 \pm 0.46^{\mathrm{a}}$ & $31.40 \pm 0.84^{\mathrm{b}}$ \\
ALT, u/l & $17.33 \pm 1.20$ & $19.22 \pm 1.91$ & $18.54 \pm 0.74$ \\
Calcium, mg /dl & $171.80 \pm 1.94^{\mathrm{c}}$ & $191.80 \pm 1.17^{\mathrm{b}}$ & $200.10 \pm 1.65^{\mathrm{a}}$ \\
Phosphorus, mg/dl & $5.30 \pm 0.91$ & $4.92 \pm 0.82$ & $4.02 \pm 0.73$
\end{tabular}

a-c Means in the same raw with different superscripts differ significantly at $\mathrm{P}<0.05$. 


\section{Economic efficiency:}

Economic efficiency (EE) estimated as price of gained weight divided by cost of feed consumed for that gain, are presented in Table (5). The replacement of berseem hay by Cassava or Prosopis (leaves \& twigs) with a treated wheat straw, it had effect on economic efficiency. This is expected as feed intake increased and price of feed unit increased by the increasing of CFM and berseem hay in G1 compared with price of feed unit in G2 and G3. The obtained results indicated that the cost of consumed feed was reduced with using of mixture from Prosopis or Cassava (leaves \& twigs) with a treated wheat straw (1.214 and 1.341L.E/h, respectively) compared to berseem hay $(2.094 \mathrm{~L} . \mathrm{E} / \mathrm{h})$. Therefore, the feed cost $/ \mathrm{kg}$ gain was reduced with substitution of berseem
(G1) by Prosopis or Cassava with a treated wheat straw in rations and the values were 12.03, 7.99 and 7.53 for G1 (berseem hay), G2 (Prosopis with a treated wheat straw) and G3 (Cassava with a treated wheat straw). Thus, the economic efficiency was the highest $(6.64 \%)$ due to feeding Cassava with a treated wheat straw (G3) followed by G2 (6.26\%) and lastly G1 (4.15\%). Similar results were observed by Ahmed et al. (2001) with substitution of Teosinte by Kochia silage and Maged et al. (2014) with substitution of berseem by Kochia in dairy goat's rations. Eissa et al. (2015) indicated that the economic efficiency was much better with combinations of Cassave and a treated wheat straw along with Prosopis Juliflora or Acacia Saligne than control (berseem hay $60 \%+40 \%$ CFM).

Table 5. Feed conversion and economic efficiency of growing Barki lambs fed the experimental rations

\begin{tabular}{lccc}
\hline \multirow{2}{*}{ Item } & \multicolumn{3}{c}{ Groups } \\
\cline { 2 - 4 } & G1 & G2 & G3 \\
\hline Total gain, (kg) & $20.90 \pm 0.08^{\mathrm{a}}$ & $18.18 \pm 0.38^{\mathrm{b}}$ & $21.41 \pm 0.40^{\mathrm{a}}$ \\
Daily body gain, (g) & $174 \pm 0.64^{\mathrm{a}}$ & $152 \pm 3.14^{\mathrm{b}}$ & $178 \pm 3.36^{\mathrm{a}}$ \\
Total DMI (g/h/d) & 942 & 738 & 804 \\
CP intake (g/h/d) & 138 & 104 & 125 \\
Feed efficiency: & & & \\
kg DM /kg gain & 5.4 & 4.8 & 4.5 \\
kg CP/kg gain & 6.60 & 5.72 & 5.84 \\
Economic efficiency: & & & \\
Cost of consumed feed, L.E/h & 2.094 & 1.214 & 1.341 \\
Price of weight gain, L.E & 8.70 & 7.60 & 8.90 \\
Feed cost/ kg gain, L.E & 12.03 & 7.99 & 7.53 \\
Economic efficiency, $\%$ & 4.15 & 6.26 & 6.64 \\
\hline
\end{tabular}

Market price (LE)/Ton fresh of ingredients: $\mathrm{BH}=1600 \mathrm{LE} ; \mathrm{CFM}=2800 \mathrm{LE}$; Cassava = 500 LE; Prosopis Juliflora $=500 \mathrm{LE} ;$ Treated wheat straw $=710 \mathrm{LE} ; \mathrm{Kg}$ live body weight of lambs $=50 \mathrm{LE}$.

\section{CONCLUSION}

In mountainous, arid, semi-arid and humid zones, shrub and tree foliage is the only feed for ruminants most of the year, so the exploitation of their full nutritional potential is vital for achieving enhanced animal productivity. A wide range of these plant species are good sources of proteins, some others are high in energy or minerals. Accordingly, feeding Cassava or Prosopis (leaves \& twigs) with ammoniated wheat straw at $60 \%$ (instead of berseem hay) + $40 \%$ concentrate feed mixture level has better impact on growing Barki lambs either for growth rate or feed conversion efficiency and economic values.

\section{REFERENCES}

A.O.A.C., 1995. Official Methods of Analysis. $\left(16^{\text {th }}\right)$ Edt. Association Analytical Chemists, Washington, D.C., USA.

Abdel- Halim, A. M., 2003. Studies of some anti- nutritional factors affecting utilization by ruminants. Ph. D. thesis, Faculty of Science, Ain Shams University.

Abdu, S.B., O.W. Ehoche, A.M. Adamu, M.R. Hassan, S.M. Yashim, H.Y. Adamu and M. Kabir, 2012. Ruminant livestock and greenhouse-gases (A Nutritionist Perspective). Iranian Journal of Applied Ani. Sci. Vol. (2), 3: 223-225.

Afaf M. Fayed, Abeer, M. El- Essawy, E.Y. Eid, H. G. Helal, Ahlam, R. Abdou and H. M. El Shaer, 2010. Utilization of alfalfa and atriplex for feeding sheep under saline conditions of South Sinai, Egypt. Journal of American Science, 6 (12): 1447- 1461.

Aganga, A. A. and S. O. Tshwenyane, 2003. Feeding Values and Anti - Nutritive Factors of Forage Tree Legumes. Pakistan Journal of Nutrition 2 (3): 170-177.

Ahmed M. E., A.M. Abdelhamid, F.F. Abou Ammou, E.S. Soliman, N.M. El-Kholy and E.1. Shehata, 2001. Response of milk production of Zaraibi goats to feeding silage containing different levels of teosinte and Kochia. Egyptian J. Nutrition and Feeds, P: 4. 
Anbarasu, C., N. Dutta and K. Sharma , 2001. Use of leaf meal mixture as a protein supplement in the ration of goats fed wheat straw. Anim. Nutr. Feed Technol. 1:113123.

Askar, A. R. T., 1998. Effect of feeding some halophytic plants on nutritional and reproductive performance for growing sheep in Sinai. M. Sc. Thesis Faculty of Agriculture. Ain Shams University.

Babayemi O. J., D. Demeyer and V. Fievez, 2004. Nutritive value and qualitative assessment of secondary compounds in seeds of eight tropical browse, shrub and pulse legumes. Comm Applied Biological Science. Ghent University 69(1):103 - 110.

Badawy, M. T., H. A. Gawish and A. A. Younis, 2002. Some physiological responses of growing Barki lambs and Baladi kids fed natural desert shrubs. International Symposium on Optimum Resources Utilization in Salt - Affect Ecosystems in Arid and Semi- arid Regions. Cairo, 8- 11, April, 496- 503.

Barry, T.N. and W.C. McNabb, 1999. The implications of condensed tannins on the nutritive value of temperate forages fed to ruminants. British Journal of Nutrition, 81: 263-272.

Barry, T.N., D.M. McNeill and W.C. McNabb, 2001. Plant secondary compounds: their impact on forage nutritive value and upon animal production. pp. 445-452, in: Proceedings of the XIX International Grassland Congress, São Pedro, São Paulo, Brazil, (2): 11-21.

Barry, T.N., T.R. Manley and S.J. Duncan, 1986. The role of condensed tannins in the nutritional value of Lotus pedunculatus for sheep. British Journal of Nutrition, 55: 123137.

Ben Salem, H., A. Nefzaoui, H. P. S. Makkar, H. Hochlef, I. Ben Salem and L. Ben Salem, 2005. Effect of early experience and adaptation period on voluntary intake, digestion and growth in Barbarine lambs given tannin - containing (Acacia cyanophylla Lindl. foliage) or tannin - free (oaten hay) diets. Anim. Feed Sci. and Tech. $122,59-77$

Ben Salem, H., I. Ben Salem, N. Nefzaoui and M.S. Ben Saï, 2003. Effect of PEG and olive cake feed blocks supply on intake, digestion and health of goats given kermes oak (Quercus coccifera L.) foliage. Animal Feed Science and Technology, (in press).

Calsamiglia, S., M. D. Stern and J. L. Firkins , 1995. Effects of protein source on nitrogen metabolism in continuous culture and intestinal digestion in vitro. J. Anim. Sci., 73: 1819 .
Coles E. H., 1986. Veterinary Clinical Pathology. $4^{\text {th }}$ Ed. Sunders W. B. Co., Philadelphia, London.

Demeyer, D. I. and C. Van Nivel, 1975. Methanogenesis, an integrated part of carbohydrate fermentation and its control. In digestion and metabolism in ruminant $(\mathrm{L} \mathrm{W}$ McDonald and A C I Warner, editors) The university of New England Publishing Unit, Armidale, N.S.W.,Australia. pp 366-382.

Eissa, M. M., EL. A. EL-Wakeel, A. M. Saber, A. R. Khattab and W. M. A. Sadek, 2015. Response of Barki lambs to diets containing Cassava and Treated wheat straw with Prosopis or Acacia Saligne (leaves \& twigs) under semi-arid area in Egypt. (under publishing).

El-Shaer, H. M., F.T. Ali, N.Y.S. Morcos, S.S. Emam and A.M. Essawy, 2005. Seasonal changes of some anti-nutritional factors contents of some halophytic shrubs and the effect of processing treatments on their utilization by sheep under desert conditions of Egypt. Egyptian J. Nutr. Feeds, 8 (1) SpecialIssue:417-431.

El-Shaer, H. M., 2010. Halophytes and salttolerant plants as potential forage for ruminants in the Near East region. Small Ruminant Research 91: pp. 3-12.

Fulkerson, W. J., A. Horadagoda, J. S. Neal, I. Barchia, K. S. Nandra, 2008. Nutritive value of forage species grown in the warm temperate climate of Australia for dairy cows: Herbs and grain crops. Livest. Sci., 114: 75-83.

Harborne, J.B., 1973. Phytochemical Methods, Chapman and Hall, Ltd., London, pp. 49188 .

Ismail, E., M. M. Anwar and S. S. Aboul ELEzz , 2003. Change in some blood constituents in sheep fed on rations containing Acacia saligna irrigated naturally or on sewage water. Alex. J. Agric. Res. 48 (3): 35- 40 .

Kumar, R., 2003. Anti-nutritive factors, the potential risks of toxicity and methods to alleviate them. http:// www.fao.org/DOCREP/003/T0632E/T0632E 10.htm.

Lowry, J. B., 1990. Toxic factors and problems: methods of alleviating them in animals. In: Shrubs and Tree Fodders for Farm Animals (Ed. C. Devendra). Proceedings of a Workshop in Denpasar, Indonesia. IDRC,Ottawa, Canada. pp. 76-88.

Maasdorp, B.V., V. Muchenje and M. Titterton, 1999. Palatability and effect of dairy cow milk yield of dried fodder from the forage trees Acacia boliviana, Calliandra calothyrsus and Leucaena leucocephala. Anim. Feed Sci. Technol. 77: 49-59. 
Maged, G.A., W. M.A. Sadek , G.I. El-Emam, M.E. El-Kholany and T.H. El-Sawah , 2014. Milk production and feed utilization of Zaraibi goats fed some forage protein sources such as berseem or Kochia silage and their mixture with fodder beet. J. Agric. Sci. Mansoura Univ. vol. 5:(12) 815

Makkar, H.P.S., 2003. Effects and fate of tannins in ruminant animals, adaptation to tannins, and strategies to overcome detrimental effects of feeding tannin rich feeds. Small ruminant Res. 49: 241-256.

Makkar, H.P.S., 2003. Effects and fate of tannins in ruminant animals, adaptation to tannins, and strategies to overcome detrimental effects of feeding tannin-rich feeds. Small Ruminant Research 49: 241- 256.

Muller, H. M., E. Leinmuller and U. Rittner, 1989. Effect of tanniferous plant material on protein and carbohydrate degradation in rumen fluid in vitro. In Recent Advance of Research. In Antinutritional Factors in Lequme Seeds. (Huisman, J.; Van der Poel, T. F. B. and Liener, I. E. eds.), pp. 156- 159, Wageningen.

NRC, 1985. Nutrient requirements of domestic animals. Nutrient requirements of sheep. National Research Council, Washington.

Nsahlai, I.V., N.N. Umunna and P.O. Osuji, 1999. Influence of feeding sheep on oilseed cake following the consumption of tanniniferous feeds. Livestock Production Science, 60: 59-69.

Ortiz, L. T., C. Centeno and J. Tervino, 1993. Tannins in faba bean seeds: effect on the digestion of protein and amino acids in growing chicks. Animal Feed Science and Technology, 41: 271- 278.

Oshodi, A.A., 1992. Proximate composition, nutritionally valuable minerals and functional properties of Adenopus breviflorus benth seed flour and protein concentrate. Food Chem., 45, 79-83.

Pasiecznik, N.M., P. Felker, P.J.C. Harris, L.N. Harsh, G. Cruz, J.C. Tewari, K. Cadoret and L.J. Maldonado, 2001. The Prosopis julifl ora-Prosopis pallida Complex: A Monograph. Henry Doubleday Research Association (HDRA). Coventry, UK. 172pp.

Patra, A.K., 2012. Enteric methane mitigation technologies for ruminant livestock: a synthesis of current research and future directions. Environmental Monitoring and Assessment. 184:1929.

Patra, A.K., D.N. Kamra and N. Agarwal, 2006. Effect of spices on rumen fermentation, methanogenesis and protozoa counts in in vitro gas production test. Int. Cong. Series. 1293, 176-179.

Patra, A.K., K. Sharma, N. Dutta and A.K. Pattanaik, 2002. Effect of partial replacement of dietary protein by a leaf meal mixture containing Leucaena leucocephala, Morus alba and Azadirachta indica on performance of goats. Asian-Aust. J. Anim. Sci., 5 (12): 1732-1737.

Phengvichith, V. and I. Ledin, 2007. Effect of feeding different levels of wilted cassava foliage (Manihot esculenta, Crantz) on the performance of growing goats. Small Ruminant Research 71(1-3), 109-116.

Reed, J. D., 1995. Nutritional toxicology of tannins and related polyphenols in forage legumes. J. Anim. Sci. 73:1516-1528.

Reed J. D., H. Soller and A. Woodward (1990). Fodder tree and straw diets for sheep: intake, growth, digestibility and the effects of phenolics on nitrogen utilization. Anim. Feed Sci. Tecknol. 30: 39.

Reed, J.D., C. Krueger, G. Rodriguez and J. Hanson, 2000. Secondary plant compounds and forage evaluation. In:Givens, D.I., Owen, E., Axford, R.F.E., Omed, H.M. (Eds.), Forage Evaluation in Ruminant Nutrition. CABPublishing, Wallingford, UK, pp. 433-448.

Rivera, D., J. Parish, 2010. Interpreting forage and feed analysis. Mississippi State University Extension Service.

SAS Institute, 2003. SAS/STATR User's Guide: statistics. Ver. 9.1, SAS Institute Inc., Cary, NC, USA.

Shaker Y. M., S. S. Abou El-Ezz and A. L. Hashem, 2008. Physiological performance of Barki male lambs fed halophytes under semi-arid conditions. J. Agric. Sci. Mansoura Univ., 33 (9): 6393- 6408.

Shaker, Y.M., N.H. Ibrahim, F. E. Younis and H.M. El Shaer, 2014. Effect of feeding some salt tolerant fodder shrubs mixture on physiological performance of Shami goats in Southern Sinai, Egypt. Journal of American Science, 10 (2s): 66- 77.

Streeter, M. N., G. M. Hill, D. G. Wagner, F. N. Owens and C. A. Hibberd, 1993. Effect of bird resistant and non bird resistant sorghum gain on amino acid digestion by beef heifers. J. Anim. Sci., 71: 1648- 1656.

Van Soest, P.J., 1965. Symposium of factors influencing the voluntary intake in relation to chemical composition and digestibility. J. Anim. Sci. 24:834.

Waghorn, G.C., M.H. Tavendale and D.R. Woodfield, 2002. Methanogenesis in forages fed to sheep. In Proc. New Zealand Grassland Association Sixty-fourth Conference, West Coast, New Zealand, 5-7 November. 64, 167-171.

Wanapat, M., O. Pimpa, A. Petlum and U. Boontao, 1997. Cassava hay: A new strategic feed for ruminants during the dry season. Livestock Research for Rural Development 9(2), 1-5. 
Wanapat, M., 2001. Role of cassava hay as animal feed in the tropics. Preston, T.R. et al. (Eds.). In: Proceeding of the International Workshop on Current Research and Development on Use Cassava as Animal Feed. Khon Kean University, Thailand.

Wheeler, B., 2003. Guidelines for feeding dairy cows. Ministry of Agriculture and Food, Government of Ontario, Canada.

Wilson, A.D., 1992. Halophytic plants communities in Australia: Ecology and potential as a rangeland resource. Proc. Inter. Workshop. Halophytes as a resource for livestock and for rehabilitation of degraded land.

Yusran, M. A. and E. Teleni, 2000. The effect of a mix of shrub legumes supplement on the reproductive performance of Pernankan Ongole cows on dryland smallholder farms in Indonesia. Asian-Aus. J. Anim. Sci. Supplement (Vol. A) 13: 481.

تأثر تغذية مخاليط مختلفة من الأثجار العلفية مع مخلفات المحاصيل المعاملة على الأداء الإنتاجى للحملان

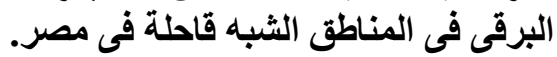

\author{
محمد محمد عيسى، وليد ماهر أمين، أحمد رجب خطاب، \\ معهج بحوث الاتتاج الحيوانس، مركز البحوث الزراعيةـ الدقى - الجبزة- مصر
}

أجري هذا البحث علي الحملان البرقى لاختبار تأثير التغذية على شجيرات علفية مع تبن القمح المعامل بالأمونيا علي معدلات النمو

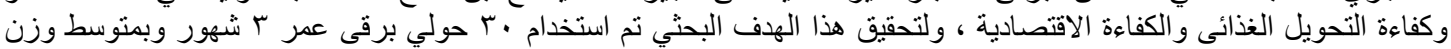

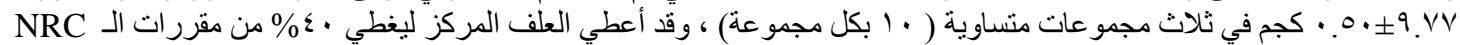

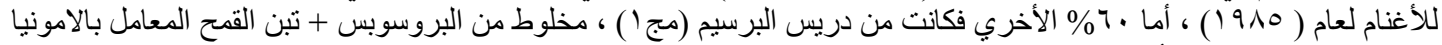

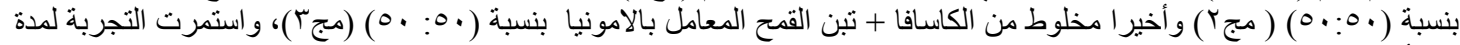

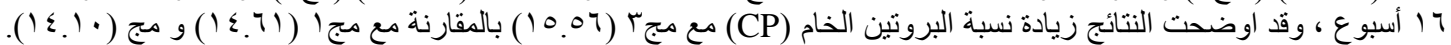

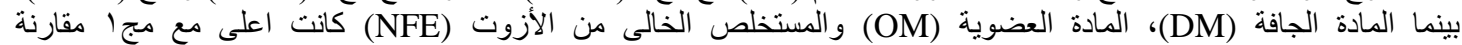

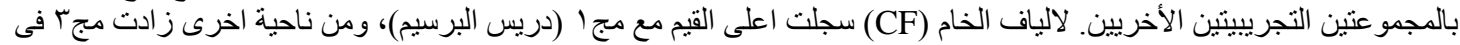

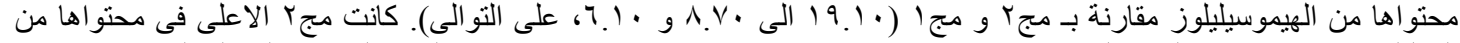

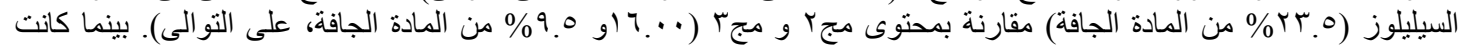

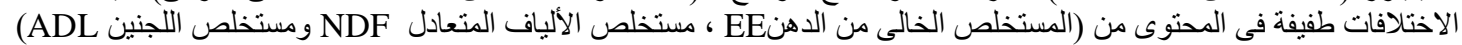

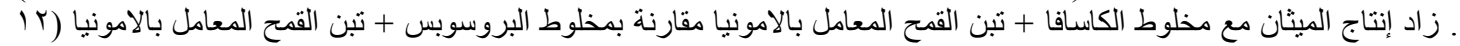

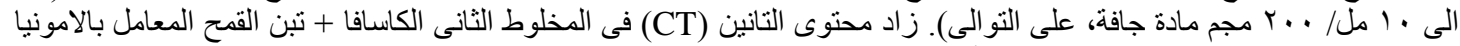

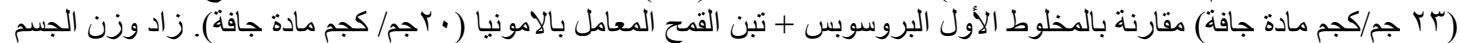

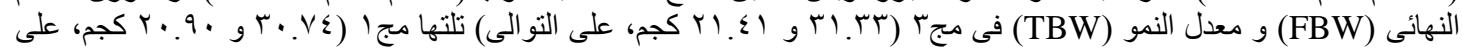

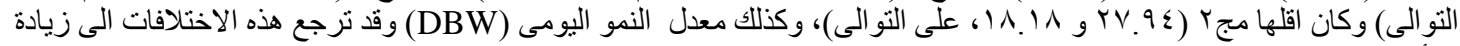

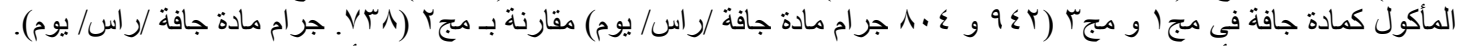

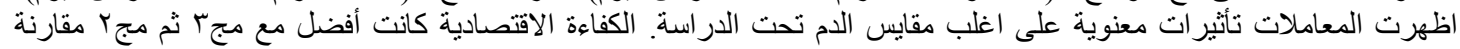

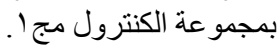

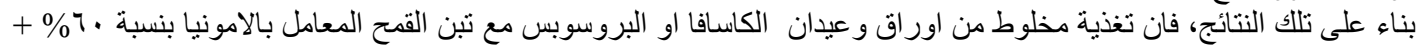

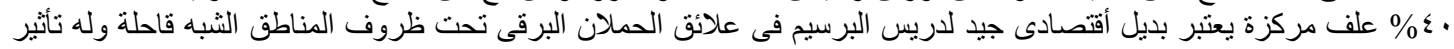
جيد على معدلات النمو ومعدلات التحويل الغذائى. 